
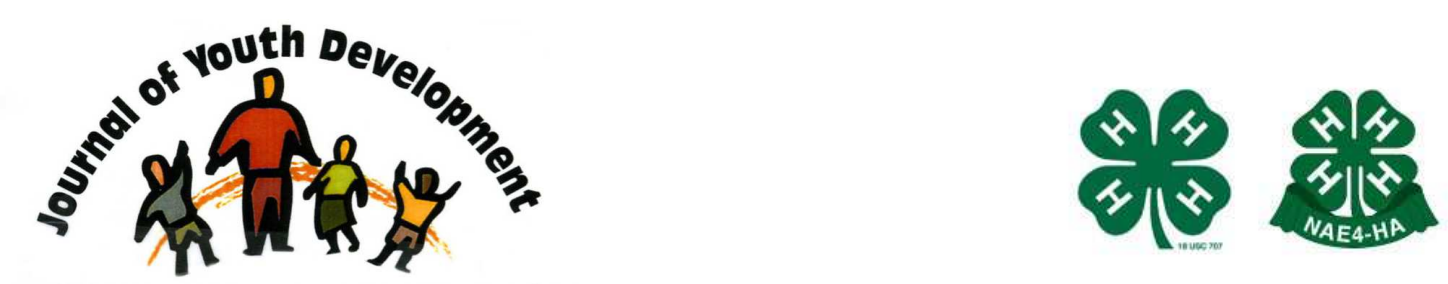

Bridging Research \& Practice

\title{
A Goal Setting Intervention Positively Impacts Adolescents' Dietary Behaviors and Physical Activity Self-Efficacy
}

\author{
Mical Kay Shilts \\ Family \& Consumer Sciences Department \\ California State University, Sacramento \\ Sacramento, CA \\ shiltsm@csus.edu
}

\author{
Marilyn S. Townsend \\ Department of Nutrition \\ University of California, Davis \\ Davis, CA \\ mstownsend@ucdavis.edu
}




\title{
JOURNAL OF YOUTH DEVELOPMENT \\ bridging research and practice

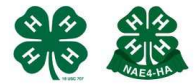

Volume 7, Number 4, Winter 2012

Article 120704PA001

\section{A Goal Setting Intervention Positively Impacts Adolescents' Dietary Behaviors and Physical Activity Self-Efficacy}

\author{
Mical Kay Shilts \\ California State University, Sacramento \\ Marilyn S. Townsend \\ University of California, Davis
}

\begin{abstract}
The efficacy of a youth development intervention on improving eating and physical activity(PA) self-efficacy, goal attainment scaling, goal effort, and behaviors was examined in a repeated measures, quasi-experimental field trial. Ethnically diverse students $(n=64)$ from a low-income middle school participated in the 10-session intervention driven by the Social Cognitive Theory with a Goal Setting Theory emphasis. Participants, $13-14$ years old, made significant changes in dietary behaviors $(P=0.03)$ and PA selfefficacy $(P=0.02)$ after receiving the intervention. Self-efficacy did not mediate dietary behavior change but did mediate the small changes made in PA. Goal effort was not a mediator of behavior change. After the intervention, more participants rated themselves as making one lasting improvement in eating $(P<0.001)$ and PA $(P<0.05)$ choices and/or were planning on making more. This study adds to a small body of research with youth supporting use of goal setting interventions for diet and PA change in low-income communities.
\end{abstract}

\section{Introduction}

Obesity is a pervasive health issue for adolescents in the United States with $34 \%$ being classified as overweight or obese (Ogden, Carroll, \& Flegal, 2008). Obesity is associated with many chronic health conditions with risk factors evident in young people (Biro, \& Wien, 2010; Kelder, Perry, Klepp, \& Lytle, 1994). These risk factors and behaviors track into adulthood and provide the rationale for youth intervention (Freedman, et al., 2005; Kelder, et al., 1994; Lytle, 2002). 
Interventions that are behaviorally focused and theory-driven are the most effective at changing youth health behaviors (Contento, et al., 1995). The Social Cognitive Theory, widely used for understanding and researching behavior change in youth, specifies goal setting as an important strategy (Bandura, 1986). Setting specific goals provides a strategy for organizing nutrition and physical activity information and skills into practical and manageable steps (Strecher, et al., 1995). Goal setting research is limited for studies focusing on youth nutrition and physical activity (Shilts, Horowitz, \& Townsend, 2004a). For youth, a literature review found only one study investigating the effectiveness of a goal-setting characteristic (Shilts, et al., 2004a; White, \& Skinner, 1988). More recently, three goal setting intervention effectiveness studies (Contento, Koch, Lee, \& Calabrese-Barton, 2010; Patrick, et al., 2006; Singh, Chin A Paw, Brug, \& van Mechelen, 2009) and a goal-setting effectiveness study (Shilts, Horowitz, \& Townsend, 2009) were reported in the literature with each showing positive results (Shilts, Townsend, \& Dishman, In Press).

Schools need education interventions that have been shown to meet needs of wellness committees, by promoting healthful eating and physical activity behaviors, and at the same time, impacting academic performance (Horowitz, Shilts, Lamp, \& Townsend, 2008). For example, the intervention, in this study was previously shown to improve academic performance measured by achievement of specific mathematics and English education standards, concomitant to its primary objective of promoting healthful eating and physical activity among low-income adolescents (Shilts, Lamp, Horowitz, \& Townsend, 2009). Schools are strongly encouraged to focus on the three R's, reading, writing and arithmetic, with minimal time for other content such as health education (Horowitz, et al., 2008). There is a clear need for short term, light intensity programs shown to have an impact on both nutrition and physical activity behaviors as well as academic performance. School wellness committees favor recommending programs shown to be effective (Horowitz, et al., 2008).

The purpose of this study was to assess efficacy of a youth development intervention targeting nutrition and physical activity behaviors with its goal setting focus in a low-income middle school setting. Specifically, outcomes on improving dietary and physical activity self-efficacy and behaviors were investigated using four analytical approaches to gain a more complete picture of intervention impact. It was hypothesized that the intervention lessons would generate significant changes in dietary and physical activity self-efficacy, which in turn would lead to changed behaviors compared to the no lesson control period. Secondarily, it was hypothesized that goal effort would mediate behavioral outcomes.

\section{Methods}

\section{Procedure}

Using a repeated measures, quasi-experimental field trial, evaluation instruments were administered to participants, three times during the Spring of 2002: baseline $\left(T_{1}\right)$, five weeks $\left(T_{2}\right)$ and 10 weeks $\left(T_{3}\right)$. During the five-week control period from $T_{1}$ to $T_{2}$, participants received their usual classroom education. During the five-week treatment period from $T_{2}$ to $T_{3}$, students participated in the intervention, delivered by the authors/researchers in one-hour sessions, twice a week. The University of California, Davis Institutional Review Board approved the study. Parents or legal guardians gave informed consent and participants gave informed assent. To support standardized and transparent reporting for nonrandomized intervention research evaluations in public health, the Transparent Reporting of Evaluations with 
Nonrandomized Designs (TREND) checklist guided the protocol (Des Jarlais, D.C., Lyles, C., Crepaz, N., \& TREND Group, 2004).

\section{Sample}

The intervention being tested in this study was designed for use by the 4-H, Expanded Food and Nutrition Education Program (EFNEP) (US Department of Agriculture (USDA)) and the Supplemental Nutrition Assistance Program-Education (SNAP-ed) (US Department of Agriculture Food and Nutrition Service (FNS)) serving low-income communities. Therefore a low-income, urban middle school in central California was targeted for the convenience sample. The participants were $8^{\text {th }}$ grade students $(n=64)$ from all five periods of a home economics course. Parental consent and student assent were received from 50 participants. Efforts to retrieve consent and assent forms continued throughout the intervention period. Those not consenting to the study received the intervention and participated in the data collection but their data was not included in analyses. Nine consented participants did not complete the evaluation instruments (e.g. some were members of families that relocated during the intervention, others had prolonged absences); therefore, 41 participants were included in the analyses. The middle school had $65 \%$ enrollment in free/reduced price meals and met criteria for participation in 4- $\mathrm{H}$, EFNEP and SNAP-Ed.

\section{Intervention}

The youth development intervention was designed to improve dietary and physical activity behaviors of middle school students living in low-income, ethnically diverse communities. Called EatFit, the 10, one-hour sessions were delivered in a classroom setting with self-efficacy, outcome expectancies, and self-regulation constructs addressed throughout the curriculum (Bandura, 1986; Horowitz, Shilts, \& Townsend, 2004). Lesson topics included nutrition and fitness basics; diet \& fitness analysis and goal setting; energy balance; food labels; breakfast; fast food; and advertising. Cultural and socio-economic factors were incorporated into the intervention such as ethnic recipes, photos of culturally diverse teens, and incorporation of culturally appropriate foods into the diet analysis program (Horowitz, Shilts, \& Townsend, 2005). Computer technology was used to assist students in diet assessment (Horowitz, et al., 2005).

Using the results of the diet assessment, the web-based program guides students to select goals. Of the three types of goal setting identified in the literature, (i.e., self-set, participatory, or assigned), no type was appropriate for the adolescent audience in a classroom setting (Shilts, 2003). A fourth type of goal setting, guided, was developed specifically for the adolescent audience, informed by focus group and individual interviews (Shilts, 2003), previous goal setting research (Locke, \& Latham, 1990; Shilts, et al., 2004a), and cognitive development theory (Piaget, 1972).

The classroom teacher does not have to assist each student in goal setting as would be the case for participatory goal setting. Guided goal setting gives choices from a collection of practitioner-developed major and minor goals with attributes necessary for optimal goal effectiveness: specificity, proximity, difficulty, and attainability (Locke, \& Latham, 2002; Shilts, Horowitz, et al., 2009; Shilts, Townsend, \& Horowitz, 2004b). Each broad major goal is coupled with a collection of minor goals that are specific in terms of what, when and how often. An example of a major goal is "Eat more fruits and vegetables" and a minor goal, "Add a fruit or vegetable to your breakfast three times this week." The adolescent makes an independent decision in selecting the major and minor goals from the carefully tailored goal options, a key element in this strategy. 
Goal progress is tracked during each lesson. Goal setting theory hypothesizes that the process of self-assessment and providing proximal, specific, difficult yet attainable goal options influence goal effort (Locke \& Latham, 1990; Locke, Shaw, Saari, \& Latham, 1981; Mento, Steel, \& Karren, 1987; Zegman \& Baker, 1983). Goal feedback and tracking focusing on accomplishments can result in enhanced self-efficacy for the goal (Strecher, DeVellis, Becker, \& Rosenstock, 1986). Effort combined with enhanced self-efficacy, increases the likelihood of behavior adoption (Locke, \& Latham, 1990; Shilts, et al., 2004a). Additional information about the intervention and guided goal setting are reported elsewhere (Horowitz, et al., 2004; Shilts, Horowitz, et al., 2009; Shilts, et al., 2004b).

The conceptual framework that guided this study was theory-driven by the Social Cognitive (Bandura, 1991) and Goal Setting (Locke \& Latham, 1990; Locke \& Latham, 2002) theories and is shown in Figure 1. Twelve intervention constructs and strategies incorporated into the development and design of the intervention components are listed. According to our framework, it is hypothesized that the intervention will influence dietary and physical activity goal effort and self-efficacy. Changes in self-efficacy could influence goal effort and vise versa so as those that are more confident will be more likely to work toward their goal. Changes in goal effort and self-efficacy will mediate behavior change. 

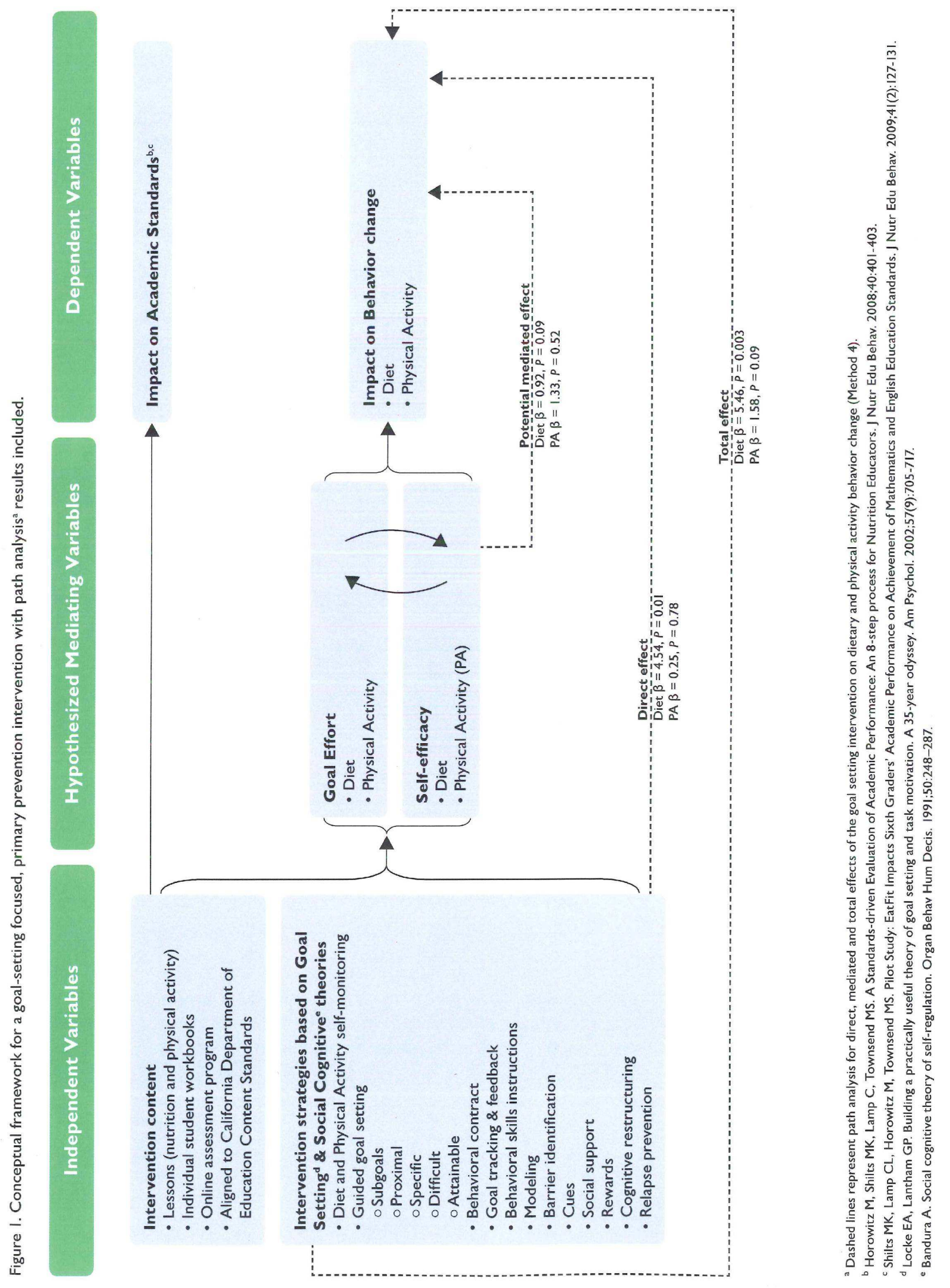
Michie and colleagues recommend that researchers and program developers describe intervention content using their taxonomy thus allowing for better comparison with similar interventions (Michie et al. 2009, Abraham \& Michie, 2008). To assist with an intervention description, 26 theory-driven behavioral 'component techniques' from 122 physical activity and healthy eating interventions focusing on five behavioral theories/models were identified (Michie and Abraham 2004; Michie et al. 2009). Previous work outlining EatFit intervention content (Horowitz, Shilts, \& Townsend, 2004) was adjusted to be compatible with the new terminology used in the recently published work of Michie, Abraham, Whittington, McAteer and Gupta (Michie et al. 2009) (Table 1). Of the 26 techniques, 14 were identified as intervention content with six of those driving the goal setting process (Table 1 ).

Table 1

Description of 14 behavioral techniques identified by Michie \& colleagues* and used in this goal setting intervention for adolescents

\begin{tabular}{|c|c|c|}
\hline Technique & Definition & Example from Intervention \\
\hline $\begin{array}{l}\text { Provide } \\
\text { information about } \\
\text { behavior-health } \\
\text { link }\end{array}$ & $\begin{array}{l}\text { Teach general information about } \\
\text { behavioral risk. }\end{array}$ & $\begin{array}{l}\text { The health benefits of eating breakfast and risks of } \\
\text { breakfast skipping are explored via a bingo game. This } \\
\text { activity helps support attainment of breakfast related } \\
\text { goals. }\end{array}$ \\
\hline $\begin{array}{l}\text { Provide } \\
\text { instruction }\end{array}$ & $\begin{array}{l}\text { Tell person how to perform a behavior } \\
\text { and/or preparatory behaviors. }\end{array}$ & $\begin{array}{l}\text { Adolescents are taught to read labels of foods specific } \\
\text { to their selected goal. }\end{array}$ \\
\hline $\begin{array}{l}\text { Model or } \\
\text { demonstrate } \\
\text { behavior }\end{array}$ & $\begin{array}{l}\text { Show person how to correctly perform } \\
\text { a behavior. }\end{array}$ & $\begin{array}{l}\text { Students interview a parent or guardian about their } \\
\text { goal setting experiences. Parents serve as a role model } \\
\text { for goal setting. }\end{array}$ \\
\hline $\begin{array}{l}\text { Prompt self- } \\
\text { monitoring of } \\
\text { behavior }\end{array}$ & Keep a record of specified behaviors. & $\begin{array}{l}\text { Based on a 24-hour food diary, students are given a } \\
\text { tailored printout providing a diet strength and two } \\
\text { areas for improvement (major goals). }\end{array}$ \\
\hline $\begin{array}{l}\text { Prompt specific } \\
\text { goal setting }\end{array}$ & $\begin{array}{l}\text { Facilitate development of a detailed } \\
\text { plan, including a definition of the } \\
\text { behavior specifying frequency, } \\
\text { intensity, or duration and specification } \\
\text { of at least one context, that is, where, } \\
\text { when, how or with whom. }\end{array}$ & $\begin{array}{l}\text { Students are guided to review the offered major goals } \\
\text { and to select one. They select one of three minor goals } \\
\text { associated with the chosen major goal. }\end{array}$ \\
\hline $\begin{array}{l}\text { Agree on } \\
\text { behavioral } \\
\text { contract }\end{array}$ & $\begin{array}{l}\text { Specify behavior to be performed so } \\
\text { that there is a written record of the } \\
\text { person's resolutions witnessed by } \\
\text { another. }\end{array}$ & $\begin{array}{l}\text { Students complete a contract. They write the major } \\
\text { and minor goals selected, sign the contract and have a } \\
\text { classmate and parent sign. }\end{array}$ \\
\hline $\begin{array}{l}\text { Provide feedback } \\
\text { on performance }\end{array}$ & $\begin{array}{l}\text { Provide data about recorded behavior } \\
\text { or evaluating performance in relation } \\
\text { to a set standard or others' } \\
\text { performance. }\end{array}$ & $\begin{array}{l}\text { During each education session, students report goal } \\
\text { effort and attainment on a tracking sheet. }\end{array}$ \\
\hline $\begin{array}{l}\text { Provide } \\
\text { contingent } \\
\text { rewards }\end{array}$ & $\begin{array}{l}\text { Praise, encouragement, or material } \\
\text { rewards that are explicitly linked to the } \\
\text { achievement of specified behaviors. }\end{array}$ & $\begin{array}{l}\text { After tracking goal effort and attainment, students } \\
\text { receive raffle tickets which are drawn for prizes. }\end{array}$ \\
\hline $\begin{array}{l}\text { Prompt review of } \\
\text { behavioral goals }\end{array}$ & $\begin{array}{l}\text { Review and/or reconsideration of } \\
\text { previously set goals or intentions. }\end{array}$ & $\begin{array}{l}\text { After tracking goal progress for four sessions, students } \\
\text { review their previously set goal and have the } \\
\text { opportunity to alter it. Many choose to make it more } \\
\text { challenging. }\end{array}$ \\
\hline
\end{tabular}




\begin{tabular}{|l|l|l|}
\hline $\begin{array}{l}\text { Prompt barrier } \\
\text { identification }\end{array}$ & $\begin{array}{l}\text { Identify barriers to performing the } \\
\text { behavior and plan ways of overcoming } \\
\text { them. }\end{array}$ & $\begin{array}{l}\text { Students discuss barriers to their goal attainment } \\
\text { during three education sessions with a focus on } \\
\text { solutions to barriers. }\end{array}$ \\
\hline Technique & Definition & Example from Intervention \\
\hline $\begin{array}{l}\text { Teach to use } \\
\text { prompts/cues }\end{array}$ & $\begin{array}{l}\text { Teach the person to identify } \\
\text { environmental cues that can be used } \\
\text { to remind them to perform a behavior. }\end{array}$ & $\begin{array}{l}\text { A lesson topic includes discussion of positive and } \\
\text { negative cues. The teacher asks, "What are some } \\
\text { negative cues that may prevent you from reaching } \\
\text { your fitness goal?" }\end{array}$ \\
\hline $\begin{array}{l}\text { Provide } \\
\text { opportunities for } \\
\text { social comparison }\end{array}$ & $\begin{array}{l}\text { Facilitate observation of non-expert } \\
\text { others' performance for example, in a } \\
\text { group class. }\end{array}$ & $\begin{array}{l}\text { Small groups are formed based on student chosen } \\
\text { goals. Students compare goal progress and goal } \\
\text { barriers. }\end{array}$ \\
\hline $\begin{array}{l}\text { Plan social } \\
\text { support }\end{array}$ & $\begin{array}{l}\text { Prompt consideration of how others } \\
\text { could change their behavior to offer } \\
\text { the person help or social support. }\end{array}$ & $\begin{array}{l}\text { Goal contracts are signed by another classmate and a } \\
\text { parent to facilitate social support. }\end{array}$ \\
\hline $\begin{array}{l}\text { Relapse } \\
\text { prevention }\end{array}$ & $\begin{array}{l}\text { Help identify situations likely to result } \\
\text { in readopting risk behaviors or failure } \\
\text { to maintain new behaviors and help } \\
\text { the person plan to avoid or manage } \\
\text { these situations. }\end{array}$ & $\begin{array}{l}\text { A lesson topic titled, "The Rest of the Story", includes } \\
\text { instruction on how to maintain, set, and achieve new } \\
\text { goals by reviewing key goal setting concepts: cues, } \\
\text { barriers, social support, rewards, desirable goal } \\
\text { attributes. }\end{array}$ \\
\hline
\end{tabular}

*Michie, S., Abraham C., Whittington, C., McAteer, J., and Gupta, S. (2009). Effective techniques in healthy eating and physical activity interventions: a meta-regression. Health Psychology, 28 (6), 690-701.

Abraham, C. and Michie, S. (2008). A taxonomy of behavior change techniques used in interventions. Health Pyschology, 27(3), 379-387.

Data Analyses

Using SAS (33) statistical software (version 9.2, 2008, SAS Institute Inc, Cary, NC) and significance at 0.05 , four approaches were used to assess outcomes:

- Method 1 - differences among the three testing periods, $T_{1}, T_{2}$, and $T_{3}$, were investigated using repeated measures analysis controlling for participant characteristics;

- Method 2 -mean change scores for the control $\left(T_{1}\right.$ and $\left.T_{2}\right)$ and treatment $\left(T_{2}\right.$ and $\left.T_{3}\right)$ periods were compared using one-tailed paired T-test;

- Method 3 - goal attainment scaling differences for $T_{2}$ and $T_{3}$ were explored using Wilcoxon signed rank test; and

- Method 4 - the mediating effect of self-efficacy and goal effort on behavioral outcomes were examined using path analysis. The total effect of the model was calculated by regressing behavior change on treatment period. The direct effect was determined by regressing behavior change on treatment period, and self-efficacy change. The direct effect coefficient was subtracted from the total effect coefficient to compute indirect or mediator effect.

\section{Measures}

A self-administered instrument assessed participants' dietary behaviors (19 items), physical activity behaviors (4 items), dietary self-efficacy (19 items), physical activity self-efficacy (4 items), goal effort (2 items) and goal attainment scaling ( 2 items). Behavior and self-efficacy items addressed the specific targeted behaviors of the intervention and corresponded to the pre-established goal options. The items in the dietary and physical activity behavior sections were adapted from the Centers for Disease Control Youth Risk Behavior Survey (YRBS) (Kolbe, Kann, \& Collins, 1993). Response range for the behavior-related items was an eight-point scale signifying the number of days per week the participant engaged in the targeted behavior, i.e., zero to seven days per week. The response range for the self-efficacy items was a four-point 
scale, i.e., one for 'not at all confident' to four for 'totally confident.' Goal commitment/effort questions asked about participants' dedication to the goal selected, i.e., 'Did you make an effort to reach your eating/ physical activity goal?' with a yes or no response option. Using the work of Thomas Kiresuk, goal attainment scaling was used to explore participant ratings of eating and physical activity behaviors before and after receiving the intervention (Kiresuk \& Sherman, 1968). Goal Attainment Scaling was developed to evaluate results of community and mental health interventions where the outcome scales could be tailored to measure specific behaviors and goals of the intervention (Kiresuk, Smith, \& Cardillo, 1994). One scale for dietary behaviors and one scale for physical activity behaviors were developed for this study with response options ranging from 'overall my eating choices have stayed the same' to 'I feel I have made at least one lasting improvement in my eating choices and I am working on making more improvements' (Table 2).

Table 2

Results for multiple methods of analysis for dietary and physical activity variables: repeated measures, paired T-test, and goal attainment scaling $(n=41)$

\begin{tabular}{|c|c|c|c|c|c|c|c|c|c|}
\hline & Time 1 & \multicolumn{2}{|c|}{ Time 2} & Time & & $\begin{array}{l}\text { Control } \\
\text { Period } \\
\left(T_{2}-T_{1}\right)\end{array}$ & $\begin{array}{r}\text { Differenc } \\
\text { Intervention } \\
\left(T_{3}-T_{2}\right)\end{array}$ & & $\begin{array}{c}\text { Interventi } \\
\text { on Period } \\
- \\
\text { Control } \\
\text { Period }\end{array}$ \\
\hline & \multicolumn{5}{|c|}{ Method 1 Repeated Measures } & \multicolumn{4}{|c|}{ Method 2 Paired T-test } \\
\hline \multicolumn{10}{|l|}{ Variables } \\
\hline Dietary Behavior & $55.34 \pm 2.14^{\mathrm{a}}$ & \multicolumn{2}{|c|}{$56.00 \pm 2.03^{\mathrm{a}}$} & \multicolumn{2}{|c|}{$61.41 \pm 2.07^{b}$} & $0.66 \pm 1.81$ & \multicolumn{2}{|l|}{$5.41 \pm 1.72^{* *}$} & $4.76 \pm 2.59 *$ \\
\hline Dietary Self-Efficacy & $53.27 \pm 1.67^{\mathrm{a}}$ & \multicolumn{2}{|c|}{$54.02 \pm 1.59^{\mathrm{a}}$} & \multicolumn{2}{|c|}{$55.54 \pm 1.66^{\mathrm{a}}$} & $0.76 \pm 1.37$ & \multicolumn{2}{|l|}{$1.51 \pm 1.20$} & $0.76 \pm 1.99$ \\
\hline$P A^{c}$ Behavior & $14.59 \pm 0.91^{\mathrm{a}}$ & \multicolumn{2}{|c|}{$14.73 \pm 0.93^{\mathrm{a}}$} & \multicolumn{2}{|c|}{$16.27 \pm 0.96^{\mathrm{a}}$} & $0.15 \pm 0.88$ & \multicolumn{2}{|l|}{$1.54 \pm 0.94 *$} & $1.39 \pm 1.46$ \\
\hline PA Self-Efficacy & $13.02 \pm 0.38^{\mathrm{a}}$ & \multicolumn{2}{|c|}{$12.93 \pm 0.35^{\mathrm{a}}$} & \multicolumn{2}{|c|}{$13.75 \pm 0.34^{b}$} & $-0.10 \pm 0.25$ & \multicolumn{2}{|l|}{$0.83 \pm 0.31^{* *}$} & $0.93 \pm 0.46^{*}$ \\
\hline \multicolumn{10}{|c|}{ Method 3 Wilcoxon Signed Rank Test } \\
\hline $\begin{array}{l}\text { Goal Attainment Scaling: Please } \\
\text { rate yourself by checking one } \\
\text { statement that best describes your } \\
\text { eating and PA choices over the past } \\
2 \text { months: }\end{array}$ & & $\begin{array}{l}\text { Eating } \\
\%\end{array}$ & $\begin{array}{l}\text { PA } \\
\%\end{array}$ & $\begin{array}{l}\text { Eating } \\
\%\end{array}$ & $\begin{array}{l}\text { PA } \\
\%\end{array}$ & & $\begin{array}{c}\text { Eating } \\
\%\end{array}$ & $\begin{array}{l}\mathrm{PA}^{*} \\
\%\end{array}$ & \\
\hline $\begin{array}{l}\text { Overall, my choices have stayed } \\
\text { the same. }\end{array}$ & -- & 54 & 37 & 17 & 15 & -- & -37 & -22 & -- \\
\hline $\begin{array}{l}\text { I have attempted to improve my } \\
\text { choices but the change didn't last } \\
\text { and I have returned to my usual } \\
\text { habits. }\end{array}$ & -- & 20 & 10 & 10 & 17 & -- & -10 & +7 & -- \\
\hline $\begin{array}{l}\text { I have made at least one lasting } \\
\text { improvement in my choices. }\end{array}$ & -- & 15 & 29 & 37 & 34 & -- & +22 & +5 & -- \\
\hline $\begin{array}{l}\text { If feel I have made at least one } \\
\text { lasting improvement in my choices } \\
\text { and I am working on making more } \\
\text { improvements. }\end{array}$ & -- & 12 & 24 & 37 & 34 & -- & +25 & $\begin{array}{c}+1 \\
0\end{array}$ & -- \\
\hline
\end{tabular}

Reliability of the YRBS items with a nationally representative sample of adolescents indicated Kappas ranging from 91.1-64.2\% (Brener, Collins, Kann, Warren, \& Williams, 1995). Using the 
concurrent method of Willis, all items adapted from the YRBS for this study were cognitively tested with individual $8^{\text {th }}$ grade students $(n=16)$, revised and retested (Willis, 1994). Items were evaluated for content validity by experts in behavioral nutrition $(n=3)$. The instrument was pilot tested with $6-8^{\text {th }}$ students $(n=34)$ and revised (Shilts, Townsend, \& Horowitz, 2002). Seventh and $8^{\text {th }}$ grade students $(n=46)$ completed the revised instrument on two occasions, three weeks apart, with no intervention (Litwin, 1995). Reliability coefficients were 0.73 for dietary behavior items, 0.55 for physical activity behavior items, 0.59 for dietary self-efficacy items and .48 for physical activity self-efficacy items. Scales and instruments used with adults are thought to have good test retest reliability with coefficients of 0.7 or greater (Litwin, 1995). The coefficients for the dietary behavior items met this criterion. The other coefficients are lower than 0.7 , indicating more random error associated with the items. Because the reliability assessments were conducted with 12-14 year olds, the results are marginally acceptable for the purposes of this study. Correlations are dependent on sample size and we recognize that data was collected from a small sample and future assessments should include more adolescents. In a separate sample collected from EFNEP youth participants over a three-year period, middle school students $(n=403)$ completed the instrument at one point in time to determine internal consistency scores using Cronbach Alpha (Litwin, 1995). Internal consistency scores were $\alpha=0.54$ for dietary behavior items $(n=19), \alpha=0.65$ for physical activity behavior items $(n=4)$, $\alpha=0.82$ for dietary self-efficacy items $(n=19)$, and $\alpha=0.72$ for physical activity self-efficacy items $(n=4)$.

\section{Results}

The mean age of the participants $(n=41)$ was $14 . \pm 0.4$ with more than half being male $(63 \%)$. Ethnicity was reported by the teacher as 37\% Asian, 27\% Hispanic, 20\% non-Hispanic white, $12 \%$ non-Hispanic black, 2\% Middle Eastern and 2\% multiethnic. Teacher-report was used, because in our previous research youth had difficulty making this determination (Townsend, Johns, Shilts, \& Farfan-Ramirez, 2006).

\section{Four Analytical Methods}

\section{1) Comparison of Means using Repeated Measures}

Dietary behavior $(P=0.01)$ and physical activity self-efficacy $(P=0.03)$ mean scores were different at the three testing times, $T_{1}, T_{2}$, and $T_{3}$ (Table 2$)$. Dietary self-efficacy $(P=0.35)$ and physical activity behavior $(P=0.23)$ mean scores were not.

\section{2) Comparison of Difference Scores Using Paired t-test}

Comparing the difference score for the control period (T2 - T1) to the difference score for the treatment period (T3 $-\mathrm{T} 2)$, participants made gains in dietary behavior scores $(P=0.03)$ and physical activity self-efficacy scores $(P=0.02)$ (Table 2$)$.

\section{3) Goal Attainment Scaling}

More participants before the intervention rated themselves as making no changes in eating choices, $54 \%$ vs. $17 \%$ (Table 2 ) compared to after the intervention. Similarly, more participants before the intervention rated themselves as making no changes in physical activity levels, $37 \%$ vs. $15 \%$. After the intervention, more participants rated themselves as making one lasting improvement in dietary (37\% vs. $12 \%, P<0.0001)$ and physical activity choices (34\% vs. $24 \%, P<0.05)$ and/or were planning to make more compared to the control period. Participants made, on average, one full point increase in the scale for dietary behaviors and 0.5 point increase for physical activity behaviors (Table 2). 


\section{4) Path Analysis}

- Self-efficacy. Approximately $80 \%$ of the change in physical activity behaviors was mediated by the self-efficacy variable $(\beta=1.33)$ while the remaining change was a direct effect of the other intervention components $(\beta=0.25)$ (Figure 1$)$. Conversely, change in dietary behaviors was primarily a direct effect of other intervention components ( $\beta=4.54)$ with a non-significant indirect effect of change in self-efficacy ( $\beta$ $=0.92$ ).

- Goal effort. Goal commitment/effort is reported by Locke to be an indicator of the success of the intervention in the organizational behavior literature (Locke, Latham, \& Erez, 1988) which has provided the foundation for goal setting research in health settings (Cullen, Baranowski, \& Smith, 2001; Shilts, et al., 2004a; Strecher, et al., 1995). Our participants were asked at $\mathrm{T}_{3}$ if they made an effort to reach their eating and physical activity goals. Although most participants reported making effort to reach their eating $(87 \%)$ and physical activity $(89 \%)$ goals, this variable did not mediate behavior change in the path analysis.

\section{Discussion}

Method 1 (repeated measures) and method 2 (paired T-test) suggest that significant change in dietary behaviors and physical activity self-efficacy occurred. These results compare favorably to studies of adolescent obesity prevention interventions of longer duration using computer tailoring (Haerens, De Bourdeaudhuij, et al., 2006; Haerens, Deforche, et al., 2006) and goal setting (Contento, et al., 2010; Singh, Chin A Paw, Brug, \& van Mechelen, 2007; Singh, et al., 2009; Singh, et al., 2006) as behavioral strategies. A recent meta-analysis found that goal setting was one of two promising intervention components to modify dietary fat, fruit and vegetable intake (Ammerman, Lindquist, Lohr, \& Hersey, 2002). Other reviews have identified four additional components as valuable for targeting childhood obesity: combining nutrition and physical activity education (Bautista-Castano, Doreste, \& Serra-Majem, 2004); ensuring developmental and cultural appropriateness (Hoelscher, Evans, Parcel, \& Kelder, 2002; Seo, \& Sa, 2010); use of computer technology (Hoelscher, et al., 2002; Seo, \& Sa, 2010); and incorporation of family involvement (Bautista-Castano, et al., 2004; Seo, \& Sa, 2010). Our intervention contained these four components (Horowitz, et al., 2004).

Assessing goal attainment scaling in Method 3 provided additional information as to why dietary behavior improved, but not physical activity behavior. Fewer students reported making one lasting improvement in physical activity behaviors (change of $+15 \%$ ) compared to dietary behaviors (change of $+47 \%$ ) after receiving the intervention. In addition, after the intervention, more students reported attempting to change physical activity behaviors but returning to usual habits (change of $+7 \%$ ) compared to dietary behaviors (change of $-10 \%$ ). This finding may explain why changes in dietary behavior and physical activity self-efficacy were observed (Methods 1 and 2) but not change in physical activity behavior. Students may have been sufficiently confident enough to try new physical activities during the intervention but not maintain them.

Path analyses (Method 4) provided information on how these changes might have occurred. The intervention leading to changed dietary behavior $(\beta=4.54, P=0.01)$ is direct i.e., using intervention components other than dietary self-efficacy. It did not operate through selfefficacy or, at least, not as it was measured. The change in self-efficacy is only marginally related to change in behavior $(\beta=0.92, P=0.09)$. Difficulties detecting relationships between self-efficacy and dietary intake in youth have been reported in the literature (Baranowski et al., 
2010). The random error associated with the mediocre reliability coefficient of $r=0.59$ for the dietary self-efficacy variable is one explanation as well as our small sample size. Another explanation for these unexpected results for dietary self-efficacy is response-shift bias (Howard, \& Dailey, 1979). Response-shift bias occurs when the participant rates himself differently postintervention after acquiring new information related to the test item causing the standard of measurement to shift from pre-intervention (Cook, \& Campbell, 1979; Howard, \& Dailey, 1979). Participants in this study may have had unrealistically high expectations for their capabilities prior to the intervention as noted on the pre-test. Similar findings in adults have been reported for self-efficacy in previous nutrition education research (Bogers, Brug, Assema, \& Dagnelie, 2004; Brug, Assema, Kok, Lenderink, \& Glanz, 1994). Presumably, participants are more realistic about their capabilities after the intervention, masking actual changes in confidence when using a traditional pre/post measure (Aiken, \& West, 1990; Howard, et al., 1979; Pratt, McGuigan, \& Katzeva, 2001; Rohs, Langone, \& Coleman, 2001; Shilts, Smith, Ontai, \& Townsend, 2008). There is some evidence to suggest that administering the self-efficacy measure retrospectively to dampen a response-shift bias may provide a more accurate reflection of change (Aiken, \& West, 1990; Pratt, et al., 2001; Rohs, et al., 2001; Shilts, et al., 2008). Comparing the analyses from Methods 1 and 2, the results are consistent.

At the same time, the physical activity path analysis is more difficult to interpret. The intervention is related to change in self-efficacy, which in turn, is related to change in behavior $(\beta=1.33)$. But the intervention is only marginally related to change in behavior in total, and not at all related in terms of direct effects $(\beta=0.25)$. One conclusion is that there is only a weak relationship between the intervention and change in physical activity behavior. However, what relationship exists appears to be almost completely mediated by change in self-efficacy. This result supports the SCT premise that increasing self-efficacy increases the likelihood of behavior change (Bandura, 1986).

Path analysis indicates that goal commitment (Method 4) did not provide any additional information clarifying intervention impact. Participants reported high goal commitment contributing some evidence that the guided goal setting process was well accepted by this adolescent audience as an appropriate technique for improving dietary behaviors and physical activity self-efficacy. Goal commitment was measured using a retrospective ( $T_{3}$ only) binary variable (i.e., 'Did you make an effort to reach your eating/ physical activity goal?' with a yes or no response option). This type of weak measure may be one reason why goal commitment did not appear as a mediator to behavior change in our study. Using the goal commitment scale developed by Klein, Wesson, Hollenbeck, Wright and DeShon with its series of questions with Likert response options may provide richer data and prove to be a more useful variable in path analyses (Klein, Wesson, Hollenbeck, Wright, \& DeShon, 2001).

Limitations of our study include a small sample size, use of self-report measures, and a quasiexperimental design. Improving the psychometric properties of the data collection tools would be valuable and increase the likelihood of capturing existing change. External generalizability is limited because the sample was from one school and not randomly drawn.

\section{Implications for Research and Practices}

The youth development intervention with a focus on guided goal setting appears to contain an appropriate behavior change strategy for this youth audience as it bridges the gap between time intensive participatory goal setting and the paternalistic approach of prescribed goals. This study adds to a small body of research with youth supporting use of goal setting interventions 
for diet and physical activity change. Future translational research should include using these pilot results to plan a large scale delivery and evaluation investigating the effectiveness of this youth development intervention using the educator as the unit of analysis.

\section{Acknowledgements}

We wish to thank Marcel Horowitz, Joyce Bishop, Larissa Leavens, Earl Merrill, Jan Peerson, and Mrs. Suzi Post and her students for helping the study come to fruition.

\section{Funding}

Funding for the evaluation study was provided by the Expanded Food and Nutrition Education Program (EFNEP) and University of California, Davis Department of Nutrition. Funding for curriculum development was provided by the Supplemental Nutrition Assistance Education Program, and EFNEP. The American Distance Education Consortium funded www.eatfit.net development and the Center for Advanced Studies in Nutrition and Social Marketing funded the pilot testing of the intervention.

\section{References}

Abraham, C., \& Michie, S. (2008). A taxonomy of behavior change techniques used in interventions. Health Psychology, 27 (3), 379-387.

Aiken, L.S., \& West, S.G. (1990). Invalidity of true experiments self-report pretest biases. Evaluation Review, 14(4), 374-390.

Ammerman, A.S., Lindquist, C.H., Lohr, K.N., \& Hersey, J. (2002). The efficacy of behavioral interventions to modify dietary fat and fruit and vegetable intake: a review of the evidence. Preventive Medicine, 35(1), 25-41. doi: S0091743502910285 [pii].

Bandura, A. (1986). Foundations of Thought and Action: A Social Cognitive Theory. Englewood Cliffs, NJ: Prentice-Hall.

Bandura, A. (1991). Social cognitive theory of self-regulation. Organizational Behavior and Human Decision Processes, 50, 248-287.

Baranowski, T., Watson, K.B., Bachman, C., Baranowski, J.C., Cullen, K.W., Thompson, D., \& Siega Riz, A.M. (2010). Self efficacy for fruit, vegetable and water intakes: Expanded and abbreviated scales from item response modeling analyses. International Journal of Behavioral Nutrition and Physical Activity, 7, 25. doi: 1479-5868-7-25 [pii] 10.1186/1479-5868-7-25.

Bautista-Castano, I., Doreste, J., \& Serra-Majem, L. (2004). Effectiveness of interventions in the prevention of childhood obesity. European Journal of Epidemiology, 19, 617-622.

Biro, F.M., \& Wien, M. (2010). Childhood obesity and adult morbidities. American Journal of Clinical Nutrition, 91(suppl), 1499S-1505S. 
Bogers, R., Brug, J., Assema, P.v., \& Dagnelie, P. (2004). Explaining fruit and vegetable consumption: the theory of planned behavior and misconception of personal intake levels. Appetite, 42, 157-166.

Brener, N.D., Collins, J.L., Kann, L., Warren, C.W., \& Williams, B.I. (1995). Reliability of the Youth Risk Behavior Survey questionnaire. American Journal of Epidemiology, 141(6), 575-580.

Brug, J., Assema, P.V., Kok, G., Lenderink, T., \& Glanz, K. (1994). Self-rated dietary fat intake: associations with objective assessment of fat, psychosocial factors, and intention to change. Journal of Nutrition Education, 26(5), 218-223.

Contento, I.R., Balch, G.I., Maloney, S.K., White, S.L., Bronner, Y.L., Paige, D.M., \& Swadener, S.S. (1995). The effectiveness of nutrition education and implications for nutrition education policy, programs, and research: A review of research. Journal of Nutrition Education, 276).

Contento, I.R., Koch, P.A., Lee, H., \& Calabrese-Barton, A. (2010). Adolescents demonstrate improvement in obesity risk behaviors after completion of Choice, Control \& Change, a curriculum addressing personal agency and autonomous motivation. Journal of the American Dietetic Association, 110, 1830-1839.

Cook, T.D., \& Campbell, D.T. (1979). Quasi-Experimentation: Design and Analysis for Field Settings. Chicago: Rand McNally.

Cullen, K.W., Baranowski, T., \& Smith, S.P. (2001). Using goal setting as a strategy for dietary behavior change. Journal of the American Dietetic Association, 101(5), 562-566.

Des Jarlais, D.C., Lyles, C., Crepaz, N., \& TREND Group. (2004). Improving the reporting quality of nonrandomized evaluations of behavioral and public health interventions: the TREND statement. American Journal of Public Health, 94(3), 361-366.

Freedman, D.S., Kettel-Khan, L., Serdula, M.K., Dietz, W.H., Srinivasan, S.R., \& Berenson, G.S. (2005). The relation of childhood BMI to adult adiposity: The Bogalusa heart study. Pediatrics, 115(1), 22-27.

Haerens, L., De Bourdeaudhuij, I, Maes, L., Vereecken, C., Brug, J., \& Deforche, B. (2006). The effects of a middle-school healthy eating intervention on adolescents' fat and fruit intake and soft drinks consumption. Public Health Nutrition, 10(5), 443-449.

Haerens, L., Deforche, B., Maes, L., Cardon, G., Stevens, V., \& De Bourdeaudhuij, I. (2006). Evaluation of a 2-year physical activity and healthy eating intervention in middle school children. Health Education Research, 21(6), 911-921.

Hoelscher, D.M., Evans, A., Parcel, G.S., \& Kelder, S.H. (2002). Designing effective nutrition interventions for adolescents. Journal of the American Dietetic Association, 102(3), S52-S63.

Horowitz, M., Shilts, M.K., Lamp, C., \& Townsend, M.S. (2008). A Standards-driven Evaluation of Academic Performance: An 8-step process for Nutrition Educators. Journal of Nutrition Education and Behavior, 40, 401-403. 
Horowitz, M., Shilts, M.K., \& Townsend, M.S. (2004). EatFit: a goal oriented intervention that challenges middle school adolescents to improve their eating and fitness choices. Journal of Nutrition Education and Behavior, 36(1), 43-44.

Horowitz, M., Shilts, M.K., \& Townsend, M.S. (2005). Adapting a diet analysis program for an adolescent audience. Journal of Nutrition Education and Behavior, 37, 43-44.

Howard, G.S., \& Dailey, P.R. (1979). Response-shift bias: a source of contamination of selfreport measures. Journal of Applied Psychology, 64(2), 144-150.

Howard, G.S., Ralph, K.M., Gulanich, N.A., Maxwell, S.E., Nance, D., \& Gerber, S.L. (1979). Internal invalidity in pretest-posttest self-report evaluations and the re-evaluation of retrospective pretests. Applied Psychological Measurement, 3, 1623.

Kelder, S.H., Perry, C.L., Klepp, K., \& Lytle, L. (1994). Longitudinal tracking of adolescent smoking, physical activity and food choice behaviors. American Journal of Public Health, 84(7), 1121-1126.

Kiresuk T.J., Smith, A., \& Cardillo, J.E. (Eds.). (1994). Goal Attainment Scaling: Applications, Theory, and Measurement. Hillsdale, New Jersey: Lawarence Erlbaum Associates.

Kiresuk, T.J., \& Sherman, R.E. (1968). Goal Attainment Scaling - General Method for Evaluating Comprehensive Community Mental Health Programs. Community Mental Health Journal, 4(6), 443-453.

Klein, H.J., Wesson, M.J., Hollenbeck, J.R., Wright, M.W., \& DeShon, R.P. (2001). The assessment of goal commitment: A measurement model meta-analysis. Organizational Behavior and Human Decision Processes, 85(1), 32-55.

Kolbe, L.J., Kann, L., \& Collins, J.L. (1993). Overview of the Youth Risk Behavior Surveillance System. Public Health Reports, 108 Suppl 1, 2-10.

Litwin, M. (1995). How to Measure Survey Reliability and Validity. Thousand Oaks, CA: Sage Publications.

Locke, E.A., \& Latham, G.P. (1990). A Theory of Goal Setting and Performance. Englewood Cliffs, NJ: Prentice-Hall.

Locke, E.A., \& Latham, G.P. (2002). Building a practically useful theory of goal setting and task motivation. A 35-year odyssey. Am Psychologist, 579), 705-717.

Locke, E.A., Latham, G.P., \& Erez, M. (1988). The determinants of goal commitment. Academy of Management Review, 13(1), 23-39.

Locke, E.A., Shaw, K.N., Saari, L.M., \& Latham, G.P. (1981). Goal setting and task performance: 1969-1980. Psychological Bulletin, 90(1), 125-152.

Lytle, L.A. (2002). Nutritional issues for adolescents. Journal of the American Dietetic Association, 102(3), S8-S12. 
Mento, A.J., Steel, R.P., \& Karren, R.J. (1987). A meta-analytic study of the effects of goal setting on task performance. Organizational Behavior and Human Decision Processes, 39, 5283.

Michie, S., Abraham C., Whittington, C., McAteer, J., \& Gupta, S. (2009). Effective techniques in healthy eating and physical activity interventions: a meta-regression. Health Psychology, 28 (6), 690-701.

Michie, S., \& Abraham, C. (2004). Interventions to change health behaviours: Evidence-based or evidence-inspired? Psychology \& Health, 19 (1), 29-49.

Ogden, C., Carroll, M., \& Flegal, K. (2008). High body mass index for age among US children and adolescents. Journal of the American Medical Association, 299, 2401-2405.

Patrick, K., Calfas, K.J., Norman, G.J., Zabinski, M.F., Sallis, J.A., Rupp, J., \& Cella, J. (2006). Randomized Controlled Trial of a Primary Care and Home-Based Intervention for Physical Activity and Nutrition Behaviors. Archives of Pediatric Adolescent Medicine, 160, 128-136.

Piaget, J. (1972). Intellectual evolution from adolescence to adulthood. Human Development, $15,1-12$.

Pratt, C., McGuigan, W., \& Katzeva, A. (2001). Measuring program outcomes: using retrospective pretest methodology. American Journal of Evaluation, 21, 341-349.

Rohs, F.R., Langone, C.A., \& Coleman, R.K. (2001). Response shift bias: a problem in evaluating nutrition training using self-report measures. Journal of Nutrition Education, 33(3), 165-170.

Seo, D.C., \& Sa, J. (2010). A meta-analysis of obesity interventions among US minority children. Journal of Adolescent Health, 46, 309-323.

Shilts, M.K. (2003). The Effectiveness of Guided Goal Setting on Dietary and Physical Activity Self-efficacy and Behaviors of Middle School Adolescents. Dissertation, University of California, Davis, Davis.

Shilts, M.K., Horowitz, M., \& Townsend, M.S. (2004a). Goal setting as a strategy for dietary and physical activity behavior change: a review. American Journal of Health Promotion, 19(2), 8193.

Shilts, M.K., Horowitz, M., \& Townsend, M.S. (2009). Guided Goal Setting: Effectiveness in a dietary and physical activity intervention with low-income adolescents. International Journal of Adolescent Medicine and Health, 20(1), 111-122.

Shilts, M.K., Lamp, C.L., Horowitz, M., \& Townsend, M.S. (2009). Pilot Study: EatFit Impacts Sixth Graders' Academic Performance on Achievement of Mathematics and English Education Standards. Journal of Nutrition Education and Behavior, 41(2), 127-131.

Shilts, M.K., Smith, D., Ontai, L., \& Townsend, M.S. (2008). Evidence to support the use of the retrospective pretest method to measure dietary and physical activity behavior and self-efficacy in adolescents. Journal of Youth Development, 3(1), \#080301RS080002. 
Shilts, M.K., Townsend, M., \& Dishman, R.K. (In Press). Using Goal Setting to Promote Health Behavior Change: Diet and Physical Activity. In E. A. Locke \& G. P. Latham (Eds.), New Developments in Goal Setting and Task Performance, New York, NY: Routledge.

Shilts, M.K., Townsend, M.S., \& Horowitz, M. (2002). Pilot study of the EatFit intervention to determine sample size and protocol for a randomized controlled trial (pp. Available at: http://socialmarketing-nutrition.ucdavis.edu/publications.htm\#review6. Accessed June 28, 2006.): Center for Advanced Studies in Nutrition and Social Marketing, University of California, Davis.

Shilts, M.K., Townsend, M.S., \& Horowitz, M. (2004b). An innovative approach to goal setting for adolescents: guided goal setting. Journal of Nutrition Education and Behavior, 36(3), 155156.

Singh, A.S., Chin A Paw, M.J.M., Brug, J., \& van Mechelen W. (2007). Short-term effects of school-based weigth gain prevention among adolescents. Archives of Pediatric Adolescent Medicine. 161, 565-571.

Singh, A.S., Chin A Paw, M.J.M., Brug, J., \& van Mechelen W. (2009). Dutch obesity intervention in teenagers. Archives of Pediatric Adolescent Medicine, 163(4), 309-317.

Singh, A.S., Chin A Paw, M.J.M., Kremers, S.P.J., Visscher, T.L.S., Brug, J., \& van Mechelen, W. (2006). Design of the Dutch obesity intervention in teenagers (NRG-DOiT): systematic development, implementation and evaluation of a school-based intervention aimed at the prevention of excessive weight gain in adolescents. BMC Public Health, 6, 304. doi: $10.1186 / 1471-2458-6-304$.

Strecher, V.J., DeVellis, B.M., Becker, M.H., \& Rosenstock, I.M. (1986). The role of self-efficacy in achieving health behavior change. Health Educucation Quarterly, 13(1), 73-91.

Strecher, V.J., Seijts, G.H., Kok, G.J., Glasgow, R., DeVillis, B., Meertens, R.M., \& Bulger, D.W. (1995). Goal setting as a strategy for health behavior change. Health Educucation Quarterly 22(2), 190-200.

Townsend, M.S., Johns, M., Shilts, M.K., \& Farfan-Ramirez, L. (2006). Evaluation of a USDA nutrition education program for low-income youth. Journal of Nutrition Education and Behavior, $38(1), 30-41$.

US Department of Agriculture (USDA). (2009). Expanded Food and Nutrition Education Program (EFNEP). Retrieved May 10, 2010, from

http://www.csrees.usda.gov/nea/food/efnep/efnep.html

US Department of Agriculture Food and Nutrition Service (FNS). (2005). Food stamp nutrition education guiding principles. Retrieved May 10, 2010, from

http://www.fns.usda.gov/oane/menu/FSNE/GuidingPrinciples.pdf

White, A.A., \& Skinner, J.D. (1988). Can goal setting as a component of nutrition education effect behavior change among adolescents? Journal of Nutrition Education and Behavior, 20(6), 327-335. 
Willis, G. (1994). Cognitive Interviewing and Questionnaire Design: A Training Manual (Working Paper Series No. 7). Hyattsville, MD: Centers for Disease Control and Prevention, National Center for Health Statistics.

Zegman, M., \& Baker, B. (1983). The influence of proximal vs. distal goals on adherence to prescribed calories. Addictive Behavior, 8, 319-322.

(C) Copyright of Journal of Youth Development $~$ Bridging Research and Practice. Content may not be copied or emailed to multiple sites or posted to a listserv without copyright holder's express written permission. Contact Editor at: patricia.dawson@oregonstate.edu for details. However, users may print, download or email articles for individual use.

ISSN 2325-4009 (Print); ISSN 2325-4017 (Online) 